\title{
Soil Arthropods Diversity in Manggis Natural Reserve and Coffee Agroforestry System Kediri Regency, Indonesia
}

\author{
Dwi Suheriyanto ${ }^{1,4, a}$, Soemarno ${ }^{2, b}$, Bagyo Yanuwiadi ${ }^{3, c}$, \\ Amin Setyo Leksono ${ }^{4, d}$ \\ ${ }^{1}$ Biology Doctor Program, Biology Department, Faculty of Mathematic and Science, Brawijaya \\ University, Indonesia \\ ${ }^{2}$ Soil Department, Faculty of Agriculture, Brawijaya University, Indonesia \\ ${ }^{3}$ Biology Department, Faculty of Mathematic and Science, Brawijaya University, Indonesia \\ ${ }^{4}$ Biology Department, Faculty of Science and Technology, State Islamic University of Maulana \\ Malik Ibrahim Malang, Indonesia \\ adsuheriyanto@bio.uin-malang.ac.id, bsmno@ub.ac.id, cyanuwiadi@ub.ac.id, damin28@ub.ac.id
}

Keywords: diversity, soil arthropods, coffee, agroforestry, natural reserve

Abstract. Soil arthropods have role as herbivores, decomposers, predators and bioindicators of the various functions on ecosystems. Soil arthropods have an important role in increasing and maintaining soil productivity through the decomposition process of organic matter. The research was conducted to investigate abundance and diversity of soil arthropods in Manggis Natural Reserve and Coffee Agroforestry System. Hand-shorting methods and pitfall traps were used to catch soil arthropods. The abundance of soil arthropods were analyzed into diversity index. The result showed that the Natural Reserve has higher family number of soil arthropod and diversity index than the Agroforestry System. Individual of Hymenoptera order is very abundant in both location.

\section{Introduction}

Manggis Natural Reserve is protected forest area in Kediri regency. The Natural Reserve is located in agroforesty area that have important role to support the ecosystem sustainability and maintain biodiversity.

Agroforestry is widely promoted in Southeast Asia as a solution for developing more sustainable land uses. Agroforestry in Indonesia cover several million hectares [1]. Coffee is one of the trees planted in agroforestry systems [2]. Agroforestry system plays role in the conservation of biodiversity [3], increasing soil fertility and maintaining agricultural production [4].

Soil arthropods are important component of ecosystem. They have role as herbivores, decomposers, predators and bioindicators of the various functions on ecosystems [5]. The diversity of soil arthropods correlated with soil organic carbon and moisture [6,7]. Soil arthropods densities increas with elevated soil fertility [8].

Studies of soil fertility and nutrient status have conducted in coffee agroforestry systems [9]. The aim of this study was to investigate abundance and diversity of soil arthropods in Manggis Natural Reserve (MNR) and Coffee Agroforestry System (CAS) Kediri regency.

\section{Methodology}

Soil arthropods study was conducted at MNR $\left(07^{\circ} 50^{\prime} 45,66^{\prime \prime S} 112^{\circ} 14 ' 2,82^{\prime \prime} T\right)$ and CAS $\left(07^{\circ} 49^{\prime} 42,01^{\prime \prime} \mathrm{S} 112^{\circ} 05^{\prime} 06,42^{\prime \prime} \mathrm{T}\right)$ sub-district of Puncu, Kediri Regency, Indonesia. The soil type of study site was regosol. The age of the coffee plants were more than 30 years. The coffee plants were shaded by Leucaena leucocephala.

Sampling of soil arthropods were carried out at dry season between September until November 2013. Soil arthropods were collected from 30 sample points of every location using hand-sorted 
method and pitfall traps. Hand-sorted method was done by collecting and sorting one soil block of $25 \mathrm{~cm} \times 25 \mathrm{~cm}$ to $30 \mathrm{~cm}$ depth. The collection of the soil block was done by removing $10 \mathrm{~cm}$ depth once at a time for three times, resulting in three layers of $10 \mathrm{~cm}$ thick of soil blocks. The soil block was removed from the ground and hand-sorted for soil arthropods [10]. In every location, 30 pitfall traps were installed systematically at $4 \mathrm{~m}$ intervals. Plastic cup of about $10 \mathrm{~cm}$ mouth diameter was filled with a little $70 \%$ ethanol and a few drops of detergent. The traps were buried 24 hours in the ground with the cup mouth position must be equal with the surface of the ground [11]. The arthropods were preserved in $70 \%$ ethanol and observed under stereomicroscope for identification to the order or family levels [12]. The abundance of soil arthropods were analyzed into Shannon's diversity index. Data analysis was performed using the software Past 2.17.

\section{Results and Discussion}

Soil arthropods are found in MNR and CAS varied in number of families and individuals. The MNR has higher family number of soil arthropod and Shannon's diversity index than the CAS (Table 1).

Table 1, Soil arthropod abundance in Manggis Natural Reserve and Coffe Agroforestry System

\begin{tabular}{|l|c|c|c|c|}
\hline \multirow{2}{*}{ Order } & \multicolumn{2}{|c|}{ Manggis Natural Reserve } & \multicolumn{2}{c|}{ Coffee Agroforestry System } \\
\cline { 2 - 5 } & $\sum$ Family & $\sum$ Individual & $\sum$ Family & $\sum$ Individual \\
\hline Hymenoptera & 4 & 944 & 4 & 1254 \\
\hline Blattaria & 3 & 96 & 2 & 16 \\
\hline Isoptera & 1 & 89 & 1 & 13 \\
\hline Araneae & 7 & 72 & 7 & 21 \\
\hline Coleoptera & 11 & 70 & 6 & 138 \\
\hline Orthoptera & 3 & 69 & 2 & 68 \\
\hline Scolopendromorpha & 1 & 25 & 1 & 23 \\
\hline Hemiptera & 3 & 19 & 3 & 10 \\
\hline Isopoda & 2 & 15 & 1 & 6 \\
\hline Polydesmida & 1 & 8 & 1 & 7 \\
\hline Collembola & 1 & 4 & 0 & 0 \\
\hline Dermaptera & 2 & 2 & 1 & 1 \\
\hline Neuroptera & 1 & 2 & 1 & 1 \\
\hline Spirobolida & 1 & 2 & 1 & 2 \\
\hline Acari & 0 & 0 & 1 & 1 \\
\hline Total & 41 & 1417 & 32 & 1561 \\
\hline Shannon's diversity index & & 1.33 & & 0.84 \\
\hline
\end{tabular}

Individual of Hymenoptera order is very abundant in the both location. The CAS has higher individual number of Hymenoptera and Coleoptera order than the MNR. All of the Hymenoptera order that found in the MNR and the CAS are Formicidae family or ant. The abundant of Hymenoptera order in both location due to the fact that the ant live together make a colony and have large numbers of individual $[12,13]$. Ant is the largest group of animals that occupy various positions in the food web. The ant can be directly or indirectly role as herbivores, scavengers, generalists or predators [14].

Family number of the Coleoptera order in the MNR is higher than the CAS but individual number of Coleoptera order in the CAS is higher than the MNR. The Coleoptera order is the most diverse order of insect [12,13]. Coleoptera order is the largest group of insect in the word. There are 175 families and 350,000 spesies in the world [15].

The Blattaria and Isoptera order are very abundance in the MNR. Blattaria order is found in a wide variety of habitats including woodland, heathland and the seashore [15]. Blattaria order mostly role as saprophagous scavengers, but some eat wood and use enteric amoebae to break it down. The 
Isoptera order (termite) can eat woods or other plant matters that are rich sources of cellulose, above and below ground [16].

Collembola order is only found in the MNR while Acari order is only found in the CAS. Collembola are numerous in terrestrial ecosystem and play important role in decomposition process of dead vegetation. Hymenoptera, Coleoptera and Acari order are predator of Collembola order [17].

The MNR is characterized by the presence of Blattaria, Isoptera, and Araneae order while the CAS is characterized by Coleoptera order. Orthoptera order is moderate in the both location (Fig. $1)$.

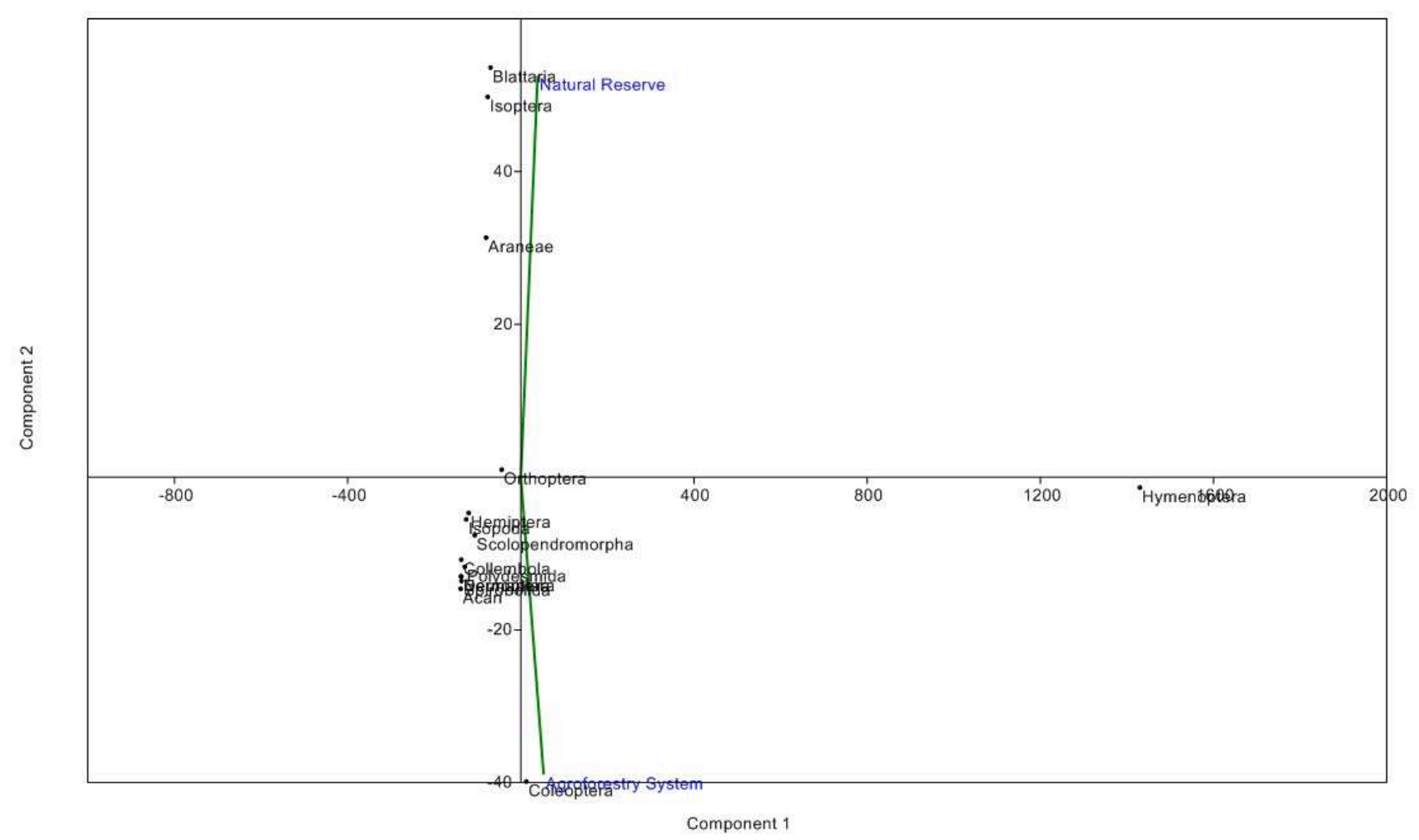

Fig. 1, PCA of soil arthropods in Manggis Natural Reserve and Coffee Agroforestry System

\section{Summary}

Soil arthropods found in Manggis Natural Reserve consists of 41 families and 1417 individuals. The number of families and individuals in Coffee Agroforestry System are 32 and 1561. Individual of Hymenoptera order is very abundant in the both location. The Natural Reserve has higher diversity index than the Coffee Agroforestry System.

\section{References}

[1] H. de Foresta, G. Michon, A. Kusworo, Complex Agroforests, International Centre for Research in Agroforestry, Bogor, 2000.

[2] K. Hairiah, Sunaryo, Widianto, Sistem Agroforestri di Indonesia, Universitas Brawijaya, Malang, 1995.

[3] S. Jose, Agroforestry for Ecosystem Services and Environmental Benefits: an Overview, Agrofor. Syst. 76 (2009) 1-10.

[4] R.C. Pinho, R.P. Miller, S.S. Alfaia, Agroforestry and the Improvement of Soil Fertility: A View from Amazonia, Appl. Environ. Soil Sci. 2012 (2012) 1-11. 
[5] M.A. Maleque, H.T. Ishii, K. Maeto, The Use of Arthropods as Indicators of Ecosystem Integrity in Forest Management, Journal of Forestry. 104 (2006) 113-117.

[6] F. Begum, R.M. Bajracharya, S. Sharma, B.K. Sitaula, Assessment of Soil Quality Using Microarthropod Communities Under Different Land System : A Case Study in the Mid-Hills of Central Nepal, Journal of Life Sciences. 5 (2011) 66-73.

[7] Sugiyarto, Keanekaragaman Makrofauna Tanah pada Berbagai Umur Tegakan Sengon, Biodiversitas. 1 (2000) 47-53.

[8] L. Cole, S.M. Buckland, R.D. Bardgett, Relating Microarthropod Community Structure and Diversity to Soil Fertility Manipulations in Temperate Grassland, Soil Biol. Biochem. 37 (2005) 1707-1717.

[9] S. Hanisch, Z. Dara, K. Brinkmann, A. Buerkert, Soil Fertility and Nutrient Status of Traditional Gayo Coffee Agroforestry Systems in The Takengon Region, Aceh Province, Indonesia, Journal of Agriculture and Rural Development in the Tropics and Subtropics. 112 (2011) 87-100.

[10]J.M. Anderson, J.S.I. Ingram, Tropical Soil Biology and Fertility: A Handbook of Methods, second ed., CAB International, Wallingford, 1993.

[11]M. Swift, D. Bignell, Standard Methods for Assessment of Soil Biodiversity and Land Use Practice, International Centre for Research in Agroforestry Southeast Asian Regional Research Programme, Bogor, 2001

[12]D.J. Borror, C.A. Triplehorn, N.F. Johnson, Pengenalan Pelajaran Serangga, Edisi Keenam, Gadjah Mada University Press, Yogyakarta, 1996.

[13]C. Gillott, Entomology, third ed., Springer, Dordrecht, 2005.

[14]J.H.C. Delabie, R. Céréghino, S. Groc, A. Dejean, , M. Gibernau, B. Corbara, A. Dejean, Ants as Biological Indicators of Wayana Amerindian Land Use in French Guiana, C. R. Biol. 332 (2009) 673-84.

[15]P.C. Barnard, The Royal Entomological Society Book of British Insects, Wiley-Blackwell, Chichester, 2011.

[16]P.J. Gullan, P.S. Cranston, The Insects: an Outline of Entomology, fourth ed., WileyBlackwell, Chichester, 2010.

[17]S.P. Hopkin, Biology of Springtails (Insecta: Collembola), Oxford University Press, Oxford, 1997. 